\section{Women and AIDS: gender relations and condom use with steady partners}

\author{
Mulheres e AIDS: relações de gênero \\ e uso do condom com parceiro estável
}

Eliana Maria Hebling 1

Isaura Rocha Figueiredo Guimarães 2
1 Centro de Pesquisas Materno-Infantis de Campinas, Campinas, Brazil.

2 Departamento de

Psicologia, Faculdade de Educação, Universidade Estadual de Campinas, Brazil.

Correspondence E. M. Hebling Centro de Pesquisas Materno-Infantis de Campinas. C. P. 6181 , Campinas, $S P$

13083-888, Brasil.

ehebling@cemicamp.org.br

\section{Abstract}

An educational project on sexuality, STDs, and AIDS was conducted for four years with some 500 women. As a result, changes were observed in HIV-related knowledge and attitudes, but not in risk behaviors for infection. This fact motivated the development of a qualitative study to learn the reasons why women failed to incorporate HIV preventive behaviors into their daily lives. Six focus groups were conducted with women who had participated in the educational project. The analysis was thematic. Women were familiar with HIV transmission routes and preventive measures. They admitted not using condoms due to fear of being suspected of infidelity and because this might lead to separation of the couple. Women reported that relationships with their partners had been difficult because of lack of dialogue and that men always had the final word. Although women had information about AIDS, they did not use preventive measures in steady relationships because they did not wield decision-making power. Gender inequality and fidelity were two significant issues related to the increase in AIDS among women.

Acquired Immunodeficiency Syndrome; Condoms; Women; Gender Relations

\section{Introduction}

AIDS has posed one of the main public health challenges worldwide. It has mobilized attention by professionals from various fields and all spheres of public and private power in the search for effective approaches to contain the epidemic $1,2,3$.

The current AIDS scenario shows trends that are quite different from the beginning, when the epidemic was mainly concentrated in the male population. Recent years have witnessed the pauperization, interiorization, and feminization of the disease 4,5. According to the Brazilian Ministry of Health, the number of female cases reported increased by $71.0 \%$ from 1994 to 1998. Official data from March 2001 showed AIDS as the leading cause of death among women 15 to 49 years of age in Brazil 6, despite the specialized, free care that was already available to persons living with HIV/AIDS.

This rapid increase in HIV infection in the female population beginning in the 1990s has been ascribed to unprotected sexual relations with partners of the opposite sex, accounting for $86.2 \%$ of the cases reported in women as of December 2002. During this same period, $83.9 \%$ of the seropositive women were in the 20 to 49 year bracket 7 . The vast majority of these women were infected by the sexual route, by their husbands or sole partners ${ }^{8}$. This fact has highlighted women's vulnerability to HIV. 
Ayres et al. 9 (p. 50) refer to vulnerability in studies on AIDS as " a concept that expresses the effort to produce and disseminate knowledge, debate, and action on the different degrees and forms of susceptibility in individuals and collective groups in relation to infection, illness, or death from HIV, according to the specificity of their situation vis-à-vis the comprehensive set of social, programmatic, and individual aspects that situates them in relation to the problem and the resources to deal with it". Women's vulnerability to HIV has been analyzed from the perspective of gender relations as a social construction 10 , to the extent that such relations involve power games, conflicts, and hierarchies that organize women's affective and love relations 11. In short, AIDS in women has called attention to the models of sexuality, revealing the ambiguous frontiers between the public and private spheres, illness, and moral transgression, and has structured the complex web of power, gender, social-class, and ethnic relations within a new scenario of tension and conflict 12 .

In 1992, the sum of these factors motivated the launching of a participatory educational project for some four years that involved some five hundred women, mothers of children enrolled in daycare centers in outlying neighborhoods of Campinas, São Paulo State, Brazil 13. During this period a course was given to subgroups of women with the objective of informing them on STD and AIDS transmission and prevention and training them as multipliers of information in their home communities. Although at the end of each course all the participants considered themselves prepared to work with AIDS prevention with other women, 97.6\% reported that they only used condoms if or when they began a new relationship, but not with the current steady partner, even when they were aware of his extramarital relations 14 .

The experience acquired with this first project, the results of which pointed to changes in knowledge and attitudes in the women, but not to self-protective behaviors against STDs/AIDS, gave rise to the study we report herein. This work reports the results of a project implemented after the one mentioned above. The new project proposed an in-depth investigation of the reasons why women failed to incorporate the AIDS prevention lessons they had learned into their daily routine.

\section{Subjects and methods}

The study employed a qualitative methodology, and the data collection technique used fo- cus groups $15,16,17,18,19$ with a previously drafted and pre-tested guide. The focus group technique includes group interviews in which a moderator leads the discussion of the proposed topics. The participants should have similar characteristics and backgrounds. The technique originated in the social sciences in the 1940s. Between 1950 and 1980 the technique migrated to the field of advertising and marketing, but returned to the social sciences beginning in the 1980s. Like the majority of qualitative data-collection techniques, focus groups require an intentional (non-random) sample of participants, according to the objectives and purposes of the research 18 .

The study included visits to six daycare centers that were still involved in the maintenance activities for the first project, described above. In each daycare center, women were invited who had already participated in the previous project, and they all agreed to participate in the focus groups.

Six focus groups were held with a total of 36 women, whose characteristics are described in Table 1. The groups were all conducted by the same three persons, who had experience in this technique. One was a moderator (the principal author) and the other two were rapporteurs. The discussions were recorded in writing and taped with the participants' authorization. The tapes were transcribed by one individual and the transcriptions revised by another, allowing to check and complement the information. A thematic analysis was performed, based on the analytical categories defined from the thematic guide and the content of the group discussions.

The categories emerging from the women's reports were considered for analysis as follows: information, feelings, and attitudes towards STDs and AIDS; risk perceptions related to infection; use of preventive measures; relationship as a couple, and power relations; fidelity and trust; and expectations as to the "ideal partner".

Women's participation was voluntary, by means of oral consent, especially relevant in studies on sensitive issues. The protocol was approved by the Research Project Evaluation Committee of the Department of Psychology, School of Education, State University in Campinas, São Paulo, in keeping with the prevailing ethical standards at the University at the time of the study. 


\section{Results}

Information, feelings, and attitudes towards STDs and AIDS

The women demonstrated that they knew the HIV transmission routes, referring to: direct contact with blood through transfusions and sharing needs and syringes; contact with secretions during sexual relations; and mother-tochild transmission during pregnancy, childbirth, and breastfeeding. They reported that STDs are dangerous and require treatment, which for them is difficult to access: "it's difficult to go to the doctor. I think I wouldn't have time, and it would be expensive, so I think I wouldn't be able to afford the medicine, understand?".

Although all the transmission routes were cited during the focus groups, the women considered heterosexual transmission as posing the greatest risk of infection for them. They acknowledged that one of the requirements for STD/AIDS prevention is information. Some also mentioned that by participating in the educational project, they had learned about the issue and felt capable of teaching other women: "it was explained in all the little details in the course we took. It was easy to pick up from the leaflets, videos, and all. Both AIDS and all the other diseases, it was easy to learn".

\section{Risk perception related to infection}

As perceived by the women, persons who use injected drugs and those with multiple sex partners are those that run the greatest risk of acquiring HIV. They mentioned that women whose partners have other relationships are more exposed to infection: "two kinds of women run the greatest risk: the one who stays home and trusts her husband, and the one who turns tricks".

The women mentioned that adolescent girls are at great risk of becoming infected with STDs and HIV, because they are constantly switching boyfriends, have greater sexual freedom in their relationships, and do not take preventive measures: "nowadays, young girls, like 12, 13 years old, are no longer virgins, and they go out with anybody". "I doubt if they protect themselves, because they go for it and get pregnant in no time. So it's because they didn't protect themselves, right? They're running the risk of both things [pregnancy and disease]".

Infidelity, multiple partners, and lack of incorporation of condom use were considered the main factors accounting for the increase in

\begin{tabular}{|c|c|}
\hline \multicolumn{2}{|c|}{$\begin{array}{l}\text { Characteristics of women in relation to condom } \\
\text { use with steady partners. Campinas, São Paulo } \\
\text { State, Brazil. }\end{array}$} \\
\hline Characteristics & $\mathrm{n}$ \\
\hline \multicolumn{2}{|l|}{ Age (years) } \\
\hline$<19$ & 1 \\
\hline $20-29$ & 11 \\
\hline $30-39$ & 14 \\
\hline$>40$ & 10 \\
\hline \multicolumn{2}{|l|}{ Schooling (years) } \\
\hline None & 7 \\
\hline $1-4$ & 22 \\
\hline $5-8$ & 4 \\
\hline $9-11$ & 3 \\
\hline \multicolumn{2}{|l|}{ Marital status } \\
\hline Married/living together & 29 \\
\hline Separated/divorced & 5 \\
\hline Widow & 2 \\
\hline \multicolumn{2}{|l|}{ Number of partners } \\
\hline 1 & 24 \\
\hline $2-3$ & 11 \\
\hline$>3$ & 1 \\
\hline \multicolumn{2}{|l|}{ Condom use } \\
\hline Never & 30 \\
\hline As contraceptive method & 6 \\
\hline As STD/AIDS prevention & 0 \\
\hline Total number of women & 36 \\
\hline
\end{tabular}

Number of women (absolute).

AIDS cases in women. There was a consensus in the groups that both men and women, including themselves, can become infected by an STD or HIV: "in other words, we're all in the water, so to speak, so let's start swimming”. "The ocean leaves us washed up on an island, there's no way out".

\section{Use of preventive measures}

The women mentioned the various mechanisms for prevention of STDs and AIDS, as well as the transmission routes. They emphasized condom use, reduction in the number of partners, and having one single partner. Some women even referred to sexual abstinence as the best solution for AIDS prevention, but the majority found this hypothesis impossible in practice, because they believe that sex is one of 
life's pleasures: "poor people have nothing in life to begin with, so if you can't have sex, forget about it! The only pleasure poor people have is in bed, so if you can't do it, that's no life!".

The women stated that condoms are the most effective method for preventing STDs and AIDS. However, the majority said that women and men don't like to use condoms, because they interrupt the sex act and block direct contact with the skin, interfering in the mutual pleasure: “it doesn't feel good. You don't feel that pleasure, that sensation. It's like there's something in the middle, getting in the way".

At different moments in the process, the participants commented on women's powerlessness in relation to condom use, because the decision is under the man's control: “it's a good solution, right, but it's up to the partner to use it, because my partner doesn't". "I even told him that the condom gets me more turned on and all, but he went and said: 'Isn't it me that's got to use it? So that's bull, because it turns me off"'.

In addition to the fact that men and women don't like using condoms and that their use is conditioned on the man's wishes, the participants reported that when they ask their partner to use one they can breed mistrust in the couple. This difficulty involves two reasons: they would supposedly be suggesting that their partner is being unfaithful or confessing infidelity on their own part. "He would say that I was confessing to him that I was going out with other people. He wouldn't admit that I had good reason [to ask]. It's not easy to ask". "How's she supposed to say to him: 'I know you are going out with other women, and I accept you for it'?".

Relationship as a couple, and power relations

For most of the participants, their relationships as couples had been marked by misunderstandings, arguments, and separations. In their opinion, couples are experiencing a time in which living together is difficult and full of clashes: "[relationships] are going badly. It's rare to see a couple today that's one hundred percent alright. There are all kinds of problems".

The women mentioned various factors that have hindered relations between men and women. The lack of dialogue between partners and "male chauvinism" were the most common complaints: "I think couples don't talk to each other anymore, don't talk and work things out, and he, the man, thinks he's always right. I think men want to be the real machos".

The constant preoccupation with survival, work, and housework was also cited as a factor that interferes in relationships in couples. According to these women, this leads people to fatigue and contributes to the lack of dialogue, besides facilitating the search for solutions outside the home: "for me it's just the same old routine, problems, fatigue, kids, family, so you let off steam outside, right? Outside you forget the problem, but the problems don't go away".

Frequent alcohol use by men was cited by the majority of the women as prejudicial to the relationship, by inducing men to commit physical aggression against women: "I think the problem is alcohol, right? The man comes home drunk. He doesn't want to talk, there's nothing to talk about. So sometimes the two start bickering, even fighting, and since he's drunk, it soon gets physical".

Love was a topic that was rarely mentioned during the focus groups, but whenever it did come up, it was referred to as conditioned on the attention and affection that the man devotes to the woman: “it's an illusion, love, this love that people talk about, I feel it for my children, but for nobody else. Because you feel love for a person who gives you affection, who gives you attention, that's there for you day by day, because when he starts mistreating you, the love vanishes".

Factors like lack of dialogue and understanding within the couple's relationship interfere negatively in the sexual relationship, according to the women's reported experience. According to them, dialogue, attention, and affection are important requirements for stimulating sexual desire: "if I think about his lack of understanding, about how rough he is, and a whole range of things that displease me, there's no sex for me".

In relation to decisions made by couples, the participants commented that women without paid work have no decision-making power. According to them, there is interdependence between the one who has the money and the one who has the decision-making power. In their words, the man detains the power, because: "the economy revolves around the one who works, right? That is, the one with the money," and thus "she doesn't have the right to say anything, to decide anything. In her house, he shows up, he lays down the law, and that's that".

\section{Fidelity and trust}

The women considered fidelity and trust as fundamental factors for maintaining the couple's relationship. In their opinion, fidelity is a requirement the couple to build day-to-day trust. However, they acknowledge that neither fidelity nor trust actually exist in couples' rela- 
tionships: “in steady relationships it's even rarer. What we see is that they're more unstable, and that those people don't find pleasure in these relationships, and that they're constantly looking elsewhere".

In the women's opinion, both men and women cheat, but it's easier for the woman to be faithful than for the man, because she spends more time at home. In addition, it's part of men's nature to have several women: "for us women, to cheat on the man we love is rarer. But for him, he may even like me, but if some tramp passes by and gives him the time of day, there he goes...".

The reasons for infidelity are not the same for men and women. According to the participants, men are moved by practicality, while for women it's a matter of affection: "he's looking for the practical side, because he thinks the more times he gets laid in a day, the more macho he is. But not the woman; when she discovers she can have pleasure, she's goes for it, but it's the affection that's involved".

For the women, the man cheats on his wife but doesn't want to lose her because he believes he can trust her: "he keeps the two, but he doesn't let go of the woman he's had for a long time". "You know why? Because he thinks she isn't capable of being unfaithful to him. It's precisely the man who cheats, the one that's got another woman and makes the decision to go for another, because in his mind the wife is not capable of messing around, of cheating on him".

In this sense, the women reported that the trust the man places in the woman is also related to the distrust she expresses towards her partner: "I'm jealous, and I show it. My mistrust guarantees to him that I'm faithful".

For the majority of the women, although the woman does not trust the man, in some circumstances she has to pretend like she does: "she trusts him when she has to trust him. The furniture in the house has to be shared. Either he doesn't make much money, and can't afford decent alimony, or she doesn't want to give him up to somebody else. So she pretends like she trusts him".

According to the participants, financial dependence is the factor that most contributes to accepting the partner's infidelity: "she accepts his infidelity because of the security issue, right? She's thinking more of her own security, like if she's not working: am I going to destroy my family now? How will I care for the children? How will I find a job? So she tends to accept infidelity more readily than the man".

\section{Expectations in relation \\ to the "ideal partner"}

According to the women, the partner they would like to have, or their notion of the "ideal" man, would be affectionate and attentive and have no vices. He should be a companion who takes active part in the family's life: "he shouldn't drink, shouldn't gamble, and should treat the family right. He shouldn't get home and start smashing things. He should be affectionate to the wife and kids. Because there are households where the man comes in one door and the kids go running out the other. Or the wife has to sleep at the neighbor woman's house, because otherwise he'll kill her". "He should be understanding and help with the domestic things. He should take interest in the school, in the kids' future, the house, the couple, and the family. Come home on time. I think a companion stays by your side through thick and thin, and understands you".

In addition to these attributes, the ideal partner should although be capable of dialogue, be understanding, faithful, and attentive to sex with the woman. According to the women, the woman needs affection, friendship, and understanding: "I think we need affection, because we women have like this full life, and we need affection, to have them talk to us. They don't always do it". "He's got to be affectionate, kind of horny, and faithful, faithful, of course!".

Others commented that for the man to be the ideal partner, he should respect and understand women's life better, and in order to do so he should experience the same things as the woman, from menstruation to childbirth, because that would make him appreciate her more. "He should menstruate, and have kids, you know, to know what it means to give birth. He should have some really bad cramps, the ones that turn you inside out. He should give normal birth to an 11-pound baby in a public hospital".

However, some women did not share this opinion. In their opinion motherhood is a unique experience that should continue as is, exclusive to women. "I disagree completely, because I think it's the only thing that's still ours. Men shouldn't give birth. It's such a good thing, so much our thing!".

\section{Discussion}

The results show that although women know how they should prevent STDs and AIDS - by using condoms - they feel powerless to do so, since they feel that this depends on the man's wishes. They admitted that they don't have the 
real decision-making power and were afraid of sparking suspicion of infidelity and thereby causing the couple to separate. In their opinion, the decision-making power is related to inequality in the relations between men and women within the marriage, where "the man always has the final word". Fear of separation was associated with loss of financial and affective stability provided by the male partner.

The majority of the women interviewed referred to the lack of dialogue and affection between partners, necessary to achieve a more satisfactory sex life. This probably reflects a repressive sexual upbringing since childhood, expressed in adult life as shame 20 . It is not surprising that this fact occurred in the lives of these women, because dialogue on sexuality and sex in couples is still considered a taboo by many 21,22 . Women's sexuality and the female body are silenced topics, especially in women's upbringing 23 .

The issue of fidelity in marital relations remains linked to forms of gender discrimination, to the extent that the greater the woman's economic dependence, the lesser her courage to react to her partner's cheating, even if she is aware of the risk of acquiring an STD. According to the women interviewed in this study, when there are children involved the woman feels responsible for the family and submits in silence to her husbands betrayals. In all senses of the word, the woman appears to feel forced to accept her partner's infidelity, whether by "pretending not to see" or denying the existence of the fact, which at any rate suggests that the woman's wishes are worthless in the monogamous relationship. Therefore, to believe she can demand condom use appears illusory.

For the women in this study, the fact that they thought of suggesting that their partners use condoms appears to have brought a mixture of mutually contradictory information and feelings to the surface, since the women were simultaneously afraid of becoming infected, while fearing the partner's reaction. The choice did not appear easy for them, since it involved delving deeply into the husband-wife "contract" and dealing with the consequences. In this sense, for them it was apparently preferable to remain in doubt about the partner's fidelity, while continuing in their dependence on him.

Condom use has not been easy to incorporate into couples' relationships. The negotiation, especially for regular use in steady relationships, has been a major difficulty for women. Surveys on the issue have shown that women are more incisive about condom use with casual as compared to steady partners 24 .
In addition, the implications of gender and power relations for AIDS prevention have also been found in studies conducted on the male population. A study on men's perceptions of the risk of becoming infected with HIV was reported by Guimarães 25 . The men studied did not consider themselves at risk of acquiring HIV, even when they had other female sexual partners besides their wives. They claimed two reasons for not being at risk: an association between AIDS and homosexuality (which they stated was not their case) and the fact that they knew the other partners and knew them to be trustworthy, thus not posing any risk. For these men, the notion that sustained the need for condom use was the same as that of the women in our study, i.e., distrust, infidelity, and betrayal, which should be eliminated for the good of the relationship.

Another study with men 26 showed that they did not consider themselves vulnerable to HIV or STDs in general because they did not belong to "risk groups", they had decreased their number of female partners, and they selected their female partners according to certain criteria. These men reported not using condoms, claimed that male infidelity was natural, and that wives should not ask their husbands to use condoms, because they should trust them.

The notion that male infidelity is normal and acceptable is still quite widespread in Brazilian society, as elsewhere. Women also tend to take this issue for granted, accepting the partner's extramarital relations as part of the man's behavior. This reasoning reveals a traditional gender logic whereby the female is encompassed by the male 27 . This gender issue has interfered in the clinical approach to STDs/AIDS, limiting prevention and treatment. Studies have shown that women in visits to the gynecologist for STDs and who reported that they were monogamous were not informed that they had a sexually transmitted disease acquired from the partner 28,29 .

In addition to the issues of fidelity and trust, there is widespread prejudice in relation to condom use. The women in this study reported that both men and women have little appreciation for condoms; women themselves also preferred that their partners not use condoms, claiming that they interfered in their sexual pleasure, which they also valued highly.

The women reported that men and women may be seeking satisfaction in extramarital relations, since both sexes cheat on each other. However, they identified different reasons for female and male betrayal. This discourse ap- 
pears to be echoed in the words of Rosenbaum et al. 21 (p. 231): "traditionally, it is 'expected' that men know more about sex, to initiate and lead it. It is expected of women that they be passive recipients or dedicated pupils. Supposedly, men want sex and women want love". In this sense, the expectations fueled by women in this study concerning the man as the ideal partner appear comprehensible: the companion, affectionate, a friend through thick and thin, and available for dialogue.

The prevention models used thus far also appear to contain some forms of gender discrimination. For example, condom use is promoted more intensely among women, even though it is known that men have the last word. The preventive measure that is believed to be somewhat more in women's hands is the female condom, but its affordability is beyond the financial reality of most people, and the male partner needs to agree in order for intercourse to happen using this method 30 . A reduction in the number of sexual partners is also promoted among women, although it is known that most sexually transmitted infections occur in women with one single partner 8 . The condition of subordination imposed on women to this day places them in such a way towards domestic violence, unwanted motherhood, extramarital relations, and limited access to information 31 that there appears to be no other alternative to acceptance of this stigma.

Mere Kisekka, spokesperson for the alert on the epidemic sweeping Nigeria, expressed the following thoughts on the above issues in a brief paragraph quoted by Guimarães 25 (p.

\section{Resumo}

Um projeto educativo sobre sexualidade, DST e AIDS foi realizado durante quatro anos com cerca de quinhentas mulheres. Como resultado, houve mudanças em conhecimentos e atitudes em relação ao HIV, mas não em comportamentos de risco para a infecção. Isto motivou a realização de um estudo qualitativo para conhecer as razões pelas quais as medidas de prevenção de AIDS não são incorporadas ao cotidiano das mulheres. Foram realizados seis grupos focais com mulheres que haviam participado do projeto educativo citado. A análise foi temática. As mulheres citaram todas as vias de transmissão e prevenção de AIDS. Reconheceram que não usavam condom porque tinham medo de despertar suspeita de infidelidade e provocar a separação do casal. Relataram que a relação a dois era difícil por falta de diálogo e que a palavra final era sempre do homem. Apesar das mulheres terem informação e conhecerem os riscos, não usavam medidas preventivas em relacionamento estável porque não tinham poder de decisão. Relações desiguais de gênero e
278): "women have internalized the ethic of the nobility of suffering in such a way that the pain and discomfort resulting from their reproductive and sexual lives are accepted as the very essence of women's being"; and Guimarães adds to this idea: "even a vaginal discharge is taken for granted". Neves 32, in Homem, Mulher e Medo [Man, Woman, and Fear] comments on the conservatism of Western culture, stating that women experience their femininity through procreation, belong to a "dominated group", and identify with the "dominator", helping him maintain this status quo. According to the author, women are not negligent in this process of female submission; rather, it derives from the sphere of social gender relations.

The results presented here corroborate those of other studies. However, they lead us to reflect on various factors that need to be reviewed in planning STD/AIDS prevention activities: to create prevention strategies based on fidelity, monogamy, sexual abstinence, or mere free distribution of condoms appears utopian. To promote communications within couples, encourage the defense of reproductive rights, include men's participation in sexual health issues, and disseminate the eroticization of condoms are measures that could be intensified in educational programs. Meanwhile, health professionals need to be receptive to the feelings, values, and attitudes that women and men report as interfering in the adoption of AIDS prevention practices in order to be better prepared to provide effective orientation, more appropriately targeted to people's needs.

questões relacionadas à fidelidade foram apontadas como fatores que contribuem para a disseminação do HIV nas mulheres.

Síndrome de Imunodeficiência Adquirida; Preservativos; Mulheres; Relações Entre os Gêneros

\section{Collaborators}

E. M. Hebling and I. R. F. Guimarães participated jointly in the drafting and review of the article.

\section{Acknowledgements}

We wish to thank the women who participated in this study and the individuals who contributed their time to the work. 


\section{References}

1. Chin J. Epidemiology: current and future dimensions of the HIV/AIDS pandemic in women and children. Lancet 1990; 336:221-4.

2. Bruyn M. Prevención de la transmisión perinatal del VIH. In: Gómez A, editor. Mujeres, vulnerabilidad y VIH/SIDA: un enfoque desde los derechos humanos. Cuadernos Mujer Salud 1998; 3:84-9.

3. Langer A, Nigenda G. Salud sexual y reproductiva y reforma del sector salud en América Latina y el Caribe: desafíos y oportunidades. México DF: The Population Council/Banco Interamericano de Desarrollo; 2000.

4. Dhalia C, Barreira D, Castilho EA. A AIDS no Brasil: situação atual e tendências. Bol Epidemiol AIDS 2000; Ano XIII n. 1:3-13.

5. Szwarcwald CL, Bastos FI, Esteves MA, Andrade CLT. A Disseminação da epidemia da AIDS no Brasil, no período 1987-1996: uma análise espacial. Cad Saúde Pública 2000; 16 Suppl 1:7-19.

6. Barcellos NT. AIDS, a mulher e a gravidez. Jornal da FEBRASGO 2001; 8:10-1.

7. Ministério da Saúde. Dados epidemiológicos Brasil. Tabela III - casos de AIDS em indivíduos de sexo feminino, segundo faixa etária e ano de diagnóstico. Brasil, 1983 a 2002. Bol Epidemiol AIDS 2002; Ano XVI n. 1:25.

8. Paiva V, Latorre MR, Gravato N, Lacerda R. Sexualidade de mulheres vivendo com HIV/AIDS em São Paulo. Cad Saúde Pública 2002; 18:1609-19.

9. Ayres JR, França Jr. I, Calazans G, Saletti Filho H. Vulnerabilidade e prevenção em tempos de AIDS. In: Barbosa R, Parker R, organizadores. Sexualidades pelo avesso: direitos, identidades e poder. Rio de Janeiro: Instituto de Medicina Social, Universidade do Estado do Rio de Janeiro/São Paulo: Editora 34; 1999. p. 49-72.

10. Scott JW. Gênero: uma categoria útil de análise histórica. Educação e Realidade 1995; 20:71-99.

11. Campos R. Aids: trajetórias afetivo-sexuais das mulheres. In: Bruschini C, organizador. Horizontes plurais: novos estudos de gênero no Brasil. São Paulo: Editora 34; 1998. p. 85-109.

12. Grinberg M. El problema de la mujer en la construcción médica del VIH-SIDA. Desidamos SIDA $1995 ; 1: 5-9$.

13. Hebling EM, Bellucci SB. Beehive project: education and prevention in AIDS for women. Brazil. AIDS: abstracts from Brazil. Proceedings of the Tenth International Conference on AIDS; 1994 Aug 7-12; Yokohama, Japan. Brasília: Programa Nacional de DST/AIDS, Ministério da Saúde; 1994. p. 48.

14. Hebling EM. Mulheres e AIDS: relações de gênero e condutas de risco [Master's Thesis]. Campinas: Faculdade de Educação, Universidade Estadual de Campinas; 1997.

15. The Program for Appropriate Technology in Health. Production and use of media and materials curriculum. Washington DC: The Program for Appropriate Technology in Health; 1992.

16. Denzin NK, Lincoln YS. Handbook of qualitative research. Thousand Oaks: Sage Publications; 1994.

17. Debus M. Manual para excelencia en la investigación mediante grupos focales. Washington DC: Academia para el Desarrollo Educativo/HealthCom; 1995.
18. Morgan DL, Krueger RA. The focus groups kit. Thousand Oaks: Sage Publications; 1998.

19. Ulin PR, Robinson ET, Tolley EE, McNeill ET. Qualitative methods: a field guide for applied research in sexual and reproductive health. Durham: Family Health International; 2002.

20. Cavalheiro T. Masturbação reduz estresse e TPM. http://br3.salutia.com.ar/salutia.php?id0=inicio\&id2=\&id3=340 (accessed on 23/May/2002).

21. Rosenbaum L, Sanford W, Jacobs JZ. Sexuality. In: Schuster S, editors. Our bodies, ourselves for the new century. The Boston Women's Health Book Collective. New York: Touchstone Books; 1998. p. 229-67.

22. Rome E, Reame N, Sanford W. Understanding our bodies: sexual anatomy, reproduction, and the menstrual cycle. In: Simon S, editor. Our bodies, ourselves for the new century. The Boston Women's Health Book Collective. New York: Touchstone Books; 1998. p. 269-87.

23. Salas VLB. A feminilidade: uma revisão da fala fálica. Porto Alegre: Artes Médicas; 1990.

24. Santos NJS, Buchalla CM, Fillipe EV, Bugamelli L, Garcia S, Paiva V. Mulheres HIV positivas, reprodução e sexualidade. Rev Saúde Pública 2002; 36 Suppl:12-23.

25. Guimarães CD. Mulheres, sexualidade e AIDS: um projeto de prevenção. In: Costa $\mathrm{AO}$, Amado T, organizadores. Alternativas escassas: saúde, sexualidade e reprodução na América Latina. São Paulo: Fundação Carlos Chagas/Editora 34; 1994. p. 249-81.

26. Guerriero I, Ayres JR, Hearst N. Masculinidade e vulnerabilidade ao HIV de homens heterossexuais, São Paulo, SP. Rev Saúde Pública 2002; 36 Suppl:50-60.

27. Heilborn ML, Gouveia PF. "Marido é tudo igual": mulheres populares e sexualidade no contexto da AIDS. In: Barbosa R, Parker R, organizadores. Sexualidades pelo avesso: direitos, identidades e poder. Rio de Janeiro: Instituto de Medicina Social, Universidade do Estado do Rio de Janeiro/São Paulo: Editora 34; 1999. p. 175-98.

28. Dixon-Mueller R, Wasserheit J. A cultura do silêncio. As infecções do trato reprodutivo nas mulheres do terceiro mundo. Washington DC: International Women's Health Coalition; 1993.

29. Giffin K, Lowndes CM. Gender, sexuality, and the prevention of sexually transmissible diseases: a Brazilian study of clinical practice. Soc Sci Med 1999; 48:283-92.

30. Kaler A. "It's some kind of women's empowerment": the ambiguity of the female condom as a marker of female empowerment. Soc Sci Med 2001; 52:783-96.

31. World Health Organization. HIV-infected women and their families: psychosocial support and related issues. A literature review. Geneva: World Health Organization; 2003.

32. Neves SP. Homem, mulher e medo: metáforas da relação homem-mulher. Petrópolis: Editora Vozes; 1986.

Submitted on $08 /$ Oct $/ 2003$

Final version resubmitted on $22 / \mathrm{Jan} / 2004$

Approved on 05/Feb/2004 